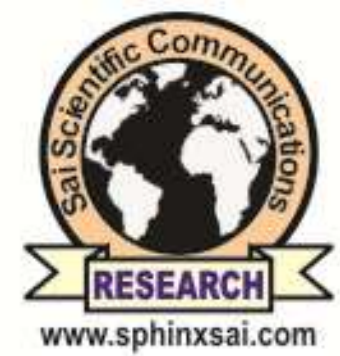

International Journal of PharmTech Research
CODEN (USA): IJPRIF, ISSN: 0974-4304, ISSN(Online): 2455-9563

Vol.13, No.01, pp 01-05,

2020

\title{
Phytopharmacological Evaluation of Alcoholic Extract of Berberis aristata Leaf in the Treatment of Gastric Ulcer
}

\author{
Ratnaker Singh ${ }^{1 *}$, Dr.Y.Trilochana ${ }^{2}$ \\ Department of Pharmacology, \\ Institute of Pharmaceutical Sciences and Research, Unnao, UP, India
}

\begin{abstract}
For over a century, peptic ulcer has been one of the most common gastrointestinal tract (GIT) disorder. There are number of drugs are now available for treatment. Drugs of herbal origin reduce the offensive factors and have proved to be safe, clinically effective, relatively less expensive, globally competitive, and with better patient tolerance.This study was performed to assess the anti-ulcer activity on different parts of B.aristata. Apart from that, acute toxicity, qualitative chemical analysis, total phenolic content (TPC), total flavonoid content(TFC) and in vitro antioxidant activities were evaluated. The potentially active plant part was selected for screening as gastro protective, in vivo antioxidant and antisecretory activities in ulcerated rats.The $50 \%$ ethanolic extract of B. aristata were subjected to preliminary phytochemical screening, estimation of TFC and TPC. The crude extract from the leaves of $B$. aristata gave best antiulcer activity among flower and stem. In acute toxicity studies, the administration of the crude extract of $B$. aristata leaves did not reveal any adverse effects or toxicity in rats at fourteen days observations. The results of these studies have shown that ethylexract of B.aristata leaf (EEBAL) produced a significant dose dependent ulcerprotective, antioxidant and antisecretory activity by blocking the activity of proton pump, protecting from antioxidants produced during stress induced ulcer and by enhancing glycoprotein levels.
\end{abstract}

Abbreviation: TPC, total phenolic content; TFC, total flavonoid content; EEBAL, ethanolic extract of Berberis aristata leaf.

\section{Introduction:}

Peptic ulcer represents a major health problem, both in terms of morbidity and mortality. The aggressive acid-pepsin factors are responsible for the induction of ulcers. Berberis aristata DC var. aristata (Berberidaceae), are commonly known as Daruharidralocal to the Himalayas in India and in Nepal. It is also found in Nilgiri slopes in South India ${ }^{\mathbf{1}, 2,3}$.The plant is utilized customarily in irritation, wound mending, skin ailment, menorrhagia, looseness of the bowels, jaundice and fondness of eyes.Alcoholic extract of bark yielded berberine chloride, palmatine chloride and a mixture of both ${ }^{4}$. The chief constituent of the roots and stem bark of $B$. aristata is an alkaloid, berberine are responsible for hepatoprotective activity ${ }^{5}$. The crude extract of B.aristata fruits exhibit preventive and curative effects on paracetamol and chloroform induced hepatotoxicity ${ }^{6}$.Berberisaristata also exhibits anti-diarrhoeal, anti-fungal, anti-histaminic an anticholinergic activities ${ }^{4}$. 


\section{Material and Methods}

\section{Plant materials}

The plant part of Berberis aristata Linn. (Family: Berberidaceae) was collected from Botanical Garden of National Botanical Research Institute (NBRI), Lucknow, India in month of Sep 2017. The plant materials authenticated by Dr. A.K.S. Rawat and the voucher specimens (NBRI-SOP-204) were deposited in the departmental herbarium (Pharmacognosy and Ethnopharmacology Division, NBRI, Lucknow) for future reference.

\section{Animals}

The adult Sprague Dawley albino rats of either sex weighing 130-180 g were taken. Pharmacological studies were carried out at National Botanical Research Institute, Lucknow.

\section{Acute Toxicity Study}

It is performed by OECD rule no. 425 following the process of Up and Down ${ }^{7,8}$.

The hydroalcohlic extract of different plant parts at doses of 400, 800 and $2000 \mathrm{mg} / \mathrm{kg} \mathrm{b.w}$ by oral gavage were given to different groups. All the animals were deprived of food for $2 \mathrm{~h}$ before and $4 \mathrm{~h}$ after dosing.The animals were continuously monitored during first $4 \mathrm{~h}$ and every one hour during the first $12 \mathrm{~h}$ for any adverse effects. Later they were monitored (daily, twice) for any abnormal changes throughout the study period (14 days).

\section{Antiulcer studies}

The EEBAL was subjected to gastroprotective studies using ethanol, aspirin, and pylorus ligation induced ulcers models. The adult Sprague Dawley albino rats of either sex weighing 140-180 g were on fasting for $48 \mathrm{~h}$ with free access to water and divided into six groups.

$\begin{array}{ll}\text { Group I } & \text { : Normal Control } \\ \text { Group II } & \text { : Ulcer control } \\ \text { Group III } & \text { : EEBAL }(100 \mathrm{mg} / \mathrm{kg} \text { b.w. p.o. }) \\ \text { Group IV } & \text { : EEBAL }(200 \mathrm{mg} / \mathrm{kg} \text { b.w. p.o. }) \\ \text { Group V } & \text { : EEBAL }(400 \mathrm{mg} / \mathrm{kg} \text { b.w. p.o. }) \\ \text { Group VI } & \text { : Ranitidine }(50 \mathrm{mg} / \mathrm{kg} \text { b.w. p.o. })\end{array}$

\section{Ethanol (EtOH)-Induced Ulcer}

After 5 days of treatment, EtOH, $(100 \%, 1 \mathrm{~mL} / 200 \mathrm{~g}, 1 \mathrm{~h})$ was administered orally on the day of the experiment and the animals were slaughtered by cervical dislocation and stomach was incised along with greater curvature and investigated for ulcers. The ulcer index was measured, based upon the product of length and width of ulcer present in stomach ${ }^{9}$.

\section{Control Ulcer Index -Test Ulcer index}

$\%$ Ulcer protection $=$

$\begin{array}{ll} & \text { x100 } \\ \text { Control Ulcer Index } & \end{array}$

$$
\text { Ulcer Index }(\mathrm{UI})=\mathrm{U}_{\mathrm{N}}+\mathrm{U}_{\mathrm{S}}+\mathrm{U}_{\mathrm{P}} / 10
$$

Where, $U_{N}=$ Average no of ulcer per rat; $U_{S}=$ Average no of severity of ulcer per rat; $U_{P}=$ percent of rat with ulcer.

\section{Aspirin (ASP) Induced Ulcer}

Following 5 days of treatment, aspirin at a portion of $200 \mathrm{mg} / \mathrm{kg} \mathrm{b.w.}(20 \mathrm{mg} / \mathrm{mL})$ was directed orally on day 6 of the investigation with the help of an orogastric tube as a suspension ${ }^{\mathbf{1 0}}$. The stomach was etched 
alongside the more prominent ebb and flow and analyzed for ulcers score.

\section{Pylorus Ligated (PL) Induced Ulcers}

Following 5 days of treatment rats were kept for $18 \mathrm{~h}$ fasting before pylorus ligation, after that the rodents were anesthetized by Pentobarbitone ( $35 \mathrm{mg} / \mathrm{kg} \mathrm{b.w,} \mathrm{IP).} \mathrm{The} \mathrm{abdomen} \mathrm{was} \mathrm{opened} \mathrm{and} \mathrm{the} \mathrm{pyloric}$ piece of the stomach was ligated. Abdomen was then sutured in two layers and rodents were left in a pan. Promptly a short time later, midriff was again opened, ligated the cardiovascular piece of the stomach and expel the stomach. The stomach was cut, opens along the more prominent ebb and flow and analyzed the ulcers on the mucosal end of the stomach ${ }^{11}$.

\section{Results}

\section{Extractive values of Berberis aristata}

The \% yield of freshly collected plant parts of Berberisaristata were shown in table1:

Table 1 : \% Yield of different parts of Berberis aristata

\begin{tabular}{|l|l|l|l|}
\hline S. No & Part used of $\boldsymbol{B}$. aristata & $\mathbf{5 0 \%}$ EtOH & \% Yield (Extract) \\
\hline $\mathbf{1 .}$ & Leaf & EtOH $: \mathrm{H}_{2} \mathrm{O}(1: 1)$ & 14.10 \\
\hline $\mathbf{2 .}$ & Flower & EtOH $: \mathrm{H}_{2} \mathrm{O}(1: 1)$ & 7.5 \\
\hline $\mathbf{3 .}$ & Bark & EtOH $: \mathrm{H}_{2} \mathrm{O}(1: 1)$ & 10.9 \\
\hline
\end{tabular}

\section{Acute Toxicity Studies}

The result indicates that there were no deformity found in all groups. The given test drug at the doses of 400,800 and $2000 \mathrm{mg} / \mathrm{kg}$ b.w was found to be safe. Accordingly, the acute oral $\mathrm{LD}_{50}$ of the extractives was completed to exceed $2000 \mathrm{mg} / \mathrm{kg} \mathrm{b} . w$, the highest dose tested in the study (Table 2).

Table 2: Mortality observation in each tested groups

\begin{tabular}{|l|l|l|l|l|l|l|l|l|l|}
\hline Plant parts & \multicolumn{3}{|c|}{ Leaf } & \multicolumn{3}{c|}{ Flower } & \multicolumn{3}{c|}{ Bark } \\
\hline Group & 1 & 2 & 3 & 1 & 2 & 3 & 1 & 2 & 3 \\
\hline Dose (mg/Kg b.w) & 400 & 800 & 2000 & 400 & 800 & 2000 & 400 & 800 & 2000 \\
\hline $\begin{array}{l}\text { Number of animal } \\
\text { dead }\end{array}$ & Nil & Nil & Nil & Nil & Nil & Nil & Nil & Nil & Nil \\
\hline
\end{tabular}

\section{Ethanol (EtOH)-Induced Ulcer}

The oral intake of EEBAL decreased the index of gastric abrasions by $13.21 .9-4.7$ 1.7, respectively (21.08 - 71.6\% protection) in comparison to control 16.6 3.9 (Table 3).

Table 3: Effect of EEBAL (twice daily for five days) on Ethanol induced gastric ulcers

\begin{tabular}{|l|l|l|l|l|}
\hline Group & Treatment & Dose $(\mathbf{m g} / \mathbf{k g})$ & Ulcer index $\left(\mathrm{mm}^{2} / \mathbf{r a t}\right)$ & Percent protection \\
\hline I & Normal Control & -- & $2.101 .41^{\#}$ & -- \\
\hline II & Disease Control & $1 \mathrm{ml} / 0.2 \mathrm{~kg}$ & 16.63 .9 & -- \\
\hline III & EEBAL & 100 & 13.21 .9 & 21.8 \\
\hline IV & EEBAL & 200 & $7.40 .94^{\mathrm{a}}$ & 55.4 \\
\hline V & EEBAL & 400 & $4.70 .71^{\mathrm{b}}$ & 71.6 \\
\hline VI & Ranitidine & 50 & $3.41 .7^{\mathrm{b}}$ & 79.51 \\
\hline
\end{tabular}




\section{Aspirin (ASP) induced ulcers}

Administration of EEBAL $1 \mathrm{~h}$ before the induction of gastric abrasions by ASP, decreased the total ulcer index of by $16.21 .6-8.40 .9$, respectively. Ranitidine lowers the total ulcer index of by $4.41 .8(78.43 \%$ protection) (Table 4).

Table 4: Effect of EEBAL extract (twice daily for five days) on Aspirin induced gastric ulcers

\begin{tabular}{|l|l|l|l|l|}
\hline Group & Treatment & Dose $(\mathbf{m g} / \mathbf{k g})$ & Ulcer index $\left(\mathbf{m m}^{2} / \mathbf{r a t}\right)$ & Percent Protection \\
\hline I & Normal Control & - & $2.101 .41^{\#}$ & -- \\
\hline II & Disease Control & 200 & 21.53 .4 & -- \\
\hline III & EEBAL extract & 100 & 16.21 .6 & 24.6 \\
\hline IV & EEBAL extract & 200 & $11.30 .75^{\mathrm{a}}$ & 47.4 \\
\hline V & EEBAL extract & 400 & $8.40 .9^{\mathrm{b}}$ & 60.9 \\
\hline VI & Ranitidine & 50 & $4.41 .8^{\mathrm{b}}$ & 78.43 \\
\hline
\end{tabular}

Values are mean \pm SEM for 6 rats;

${ }^{\#} \mathrm{P}<0.001$ as compared to their respective normal control group.

${ }^{\text {a }} \mathrm{P}<0.01$, compared to respective disease control group.

${ }^{\mathrm{b}} \mathrm{P}<0.001$ compared to respective disease control group.

\section{Pylorus ligation induced gastric ulcers}

The oral intake of EEBAL in P.L induced ulcer model decreased the ulcer index by 15.2 1.2- 4.2 0.59, respectively (16.4 -77.04\% protection) in comparison to control 18.31 .7 (Table 5).

Table 5: Effect of EEBAL extract (twice daily for five days) on Pylorus ligation induced gastric ulcers

\begin{tabular}{|l|l|l|l|l|}
\hline Group & Treatment & Dose $(\mathbf{m g} / \mathbf{k g})$ & $\begin{array}{l}\text { Ulcer index } \\
\left(\mathbf{m m}^{2} / \mathbf{r a t}\right)\end{array}$ & Percent protection \\
\hline I & Normal Control & -- & $2.101 .41^{\#}$ & -- \\
\hline II & Disease Control & -- & 18.31 .7 & -- \\
\hline III & EEBAL & 100 & 15.21 .2 & 16.4 \\
\hline IV & EEBAL & 200 & $10.50 .72^{\mathrm{a}}$ & 42.6 \\
\hline V & EEBAL & 400 & $4.20 .59^{\mathrm{a}}$ & 77.04 \\
\hline VI & Ranitidine & 50 & $3.51 .2^{\mathrm{a}}$ & 84.66 \\
\hline
\end{tabular}

Values are mean \pm SEM for 6 rats;

${ }^{\#} \mathrm{P}<0.001$ as compared to their respective normal control group ${ }^{\text {a }} \mathrm{P}<0.001$ compared to respective disease control group

\section{Discussion}

There are numerous studies identified with the antiulcerogenic properties of flavonoids ${ }^{12,13}$. Flavonoids are optional metabolite with a wide scope of organic action ${ }^{14}$. An attempt was made on the necessity of nontoxic, antioxidant and antiulcer compounds preferably from traditional medicinal plants such as $B$. aristatafor their protection against various experimental gastric ulcer models.Pylorus ligation-prompted ulcers are believed to be brought about by expanded emission of acid and pepsin in the stomach ${ }^{10}$. EEBAL would in general diminishing the acid and pepsin discharge in the stomach.Decline in gastric juice shows increment in life expectancy of mucosal cells ${ }^{15}$. Increment in mucosal defensive elements might be the central point in charge of the defensive impact of EEBAL.

\section{Conclusion}

The present examination inferred that concentrate of $B$. aristata leaf had the capacity to shield the 
gastric mucosa from synthetic (headache medicines), physical (pylorus ligation) and stress initiated ulcers by restraining gastric acid discharge, upgrading glycoprotein levels and offering cancer prevention agent insurance against oxidative pressure incited gastric harm. This finding affirms the conventional utilization of $B$. aristata leaves in the treatment of gastric ulcer.

\section{References}

1. Chauhan, N. S., 1999. Medicinal and aromatic plant of Himachal Pradesh, Indus publishing company, New Delhi, pp. 114- 116.

2. $\quad$ Sabnarn S.R.,1964. Medicinal Plants of Chamba, India, Vol 90, pp. 50-63

3. Shah,N.C.,Joshi m.c.,1971 An Ethnobotanical study of Kumaon Region of Indian economic botany, Vol. 25 pp.414-422

4. Jha N.K. (2004), 'Berberis aristata: Daruharidra: Indian Barberry', Phytopharm, 5, 9, Herbal Information Centre, New Delhi, 3-11.

5. Anonymous (2005), 'Quality Standards of Indian Medicinal Plants', 3, Indian Council of Medical Research, New Delhi, 78-87.

6. Gilani AH, Janbaz KH., 1995. Preventive and curative effects of B. aristata fruit extract on paracetamol- and CCl4- induced hepatotoxicity, Phytotherapy Research, Vol. 9, pp. 489-94.

7. OECD/OECD,OECD Guidelines for Testing of Chermicals-420,2001 Dec.

8. Dixon, W.J., 1956. The up and down methods for small animals. Journal of American Statistic Association, Vol. 60, pp. 967-978.

9. Hollander, D., Taranawski, A., Krause, W.J., Gergely, H., 1985. Protective effect of sucralfate against alcohol-induced gastric mucosal injury in the rat. Gastroenterology, Vol. 88, pp. 366-374.

10. Goel, R.K., and Bhattacharya, S.K., 1991. Gastroduodenal mucosal defence and mucosal protective agents. Indian Journal of Experimental Biology, Vol. 29, pp. 701-714.

11. Shay M., Komarov S.A.,Fels D., Meranze D.,Gruenstein H., 1945. A simple method for uniform production of gastric ulceration in the rat. Gastroe43-61nterology, Vol. 5, pp

12. Gracioso, J.S., Vilegas, W., Hiruma-Lima, C.A., Souza Brito, A.R., 2002. Effects of tea from Turneraulmifolia L. on mouse gastric mucosa support the Turneraceae as a new source of antiulcerogenic drugs. Biological and Pharmaceutical Bulletin, Vol. 25, pp. 487-491

13. Gonzalez, F.G., Di Stasi, L.C., 2002. Anti-ulcerogenic and analgesic activities of the leaves of Wilbrandia ebracteata in mice. Phytomedicine, Vol. 9, pp. 125-134

14. Harborne, J.B. Baxter, H., 1999. Handbook of Natural Flavonoids; Wiley: Chichester, UK, pp. 2

15. Guth, P., 1971. The role of microcirculation and the mast cell in stress ulcer. In: Peptic ulcer, CJ Pfeiffer eds., Munksgaard. Copenhagen, pp. 221-234 